\title{
Pro-environmental Concern of Eco-Friendly Product Users towards Environment and Society in Coimbatore City
}

\author{
V. Abirami ${ }^{1}$ and B. Gokiladevi ${ }^{2}$ \\ ${ }^{1}$ Professor and ${ }^{2}$ Research Scholar, \\ Dr. N.G.P. Arts and Science College, Coimbatore, Tamil Nadu, India.
}

CITATION: Abirami, V. and Gokiladevi, (2019), "Pro-environmental Concern of Eco-Friendly Product Users towards Environment and Society in Coimbatore City", MERC Global's International Journal of Management, Vol. 7, Issue 4, pp. 317-320.

ARTICLE HISTORY: Submitted: June 27, 2019, Revision received: August 10, 2019, Accepted: August 20, 2019

ARTICLE TYPE: Research article

\begin{abstract}
The world is facing serious environmental issues due to the era of new technology and modern development. Changes in human activities have resulted in ozone depletion and global warming. Therefore the problem of conservation has arisen to reduce the environmental damage through the consumption of eco-friendly products or organic foods. Human behaviour has undergone many revolutions in the past few decades. With this background, this paper examines the proenvironmental concern of the eco-friendly users towards the environment and society in Coimbatore City. The data was collected through the questionnaire from 350 respondents who were using ecofriendly products.
\end{abstract}

KEYWORDS: Environment, Eco-friendly, Organic, Human behaviour.

\section{BIBLIOGRAPHY}

1. Palupi, Tyas and Sawitri, Dian R. (2018), "The Importance of Pro-Environmental Behaviour in Adolescent", E3S Web of Conferences 31, 09031, ICENIS 2017, pp. 1-4

2. Steg, Linda and Viek, Charles (2009), "Encouraging pro-environmental behaviour: An integrative review and research agenda", Journal of Environmental Psychology, Vol. 20, Issue 3, September, pp. 309-317.

3. Anbukarasi, M. and Dheivanai, N. (2017), “An analytical study on consumers' awareness towards green fast-moving consumer goods in Coimbatore district", International Journal of Management Studies, Vol. 4, Special Issue 4, November, pp. 44-55. 